\title{
Phenotypic Plasticity of Pimenta pseudocaryophyllus (Gomes) Landrum Under Different Light Conditions
}

\author{
Ane Marcela das Chagas Mendonça ${ }^{1}$ (D), Jean Marcel Sousa Lira², \\ Nayara Cristina de $\mathrm{Melo}^{3}$, Marcelo Rodrigues ${ }^{4}$, \\ João Paulo Rodrigues Alves Delfino Barbosa ${ }^{1}$ \\ ${ }^{1}$ Universidade Federal de Lavras, Lavras, MG, Brasil. \\ ${ }^{2}$ Universidade Federal de Alfenas, Alfenas, MG, Brasil. \\ ${ }^{3}$ Instituto Federal de Educação Ciência e Tecnologia do Pará, Belém, PA, Brasil. \\ ${ }^{4}$ Universidade Federal do Triângulo Mineiro, Iturama, MG, Brasil.
}

\begin{abstract}
The heterogeneous light pattern in forest environments leads to specific morphological and physiological responses. However, anthropogenic pressures in areas such as Atlantic Forest and Cerrado are modifying the light availability, and consequently the forest community composition. The aim of this study was to investigate the plasticity of forest species Pimenta pseudocaryophyllus under full sunlight and shade conditions. P. pseudocaryophyllus showed typical shade plant phenotype, with higher net photosynthesis, transpiration, and chlorophyll $a$ and $b$ contents when cultivated under this condition. The decrease in net photosynthesis under full sunlight conditions is probably related to PSII photoinhibition. In addition, under full sunlight, reduced height, number of leaves, and specific leaf area was observed, while plants in shade increased these characteristics. P. pseudocaryophyllus did not show high morphological and physiological plasticity, which may be a maladaptive response. It was concluded that forest disturbances could compromise the occurrence and survival of $P$. pseudocaryophyllus.
\end{abstract}

Keywords: initial growth, RDPI, full sunlight, shade, pau-cravo. 


\section{INTRODUCTION}

Forest environments have heterogeneous light pattern due to the predominance of trees with continuous canopy (Rossatto et al., 2010; Valladares \& Niinemets, 2008). Light conditions can affect plant growth and development, modifying leaf expansion and canopy development (Wu et al., 2018). Thus forest species have some characteristics that help their survival and maximize light interception, such as high growth rate, high specific leaf area, high chlorophyll content, low leaf thickness, in addition to low nitrogen investment per leaf area (Franco et al., 2014; Gotsch et al., 2010; Mathur et al., 2018; Valladares \& Niinemets, 2008; Wu et al., 2018).

However, some human actions have abruptly modified the dynamics of forest radiation. Such events could result in alteration of vegetation types, their range shifts, and the crowding of trees (Nicotra et al., 2010), modifying light availability, and consequently plant growth, leaf area production, and the known patterns of community composition (Pinheiro et al., 2016; Silva \& Horwath, 2013; Valladares \& Niinemets, 2008). Cerrado and Atlantic forest are among the domains most affected by such changes, which puts several species at risk (Franco et al., 2014; Scarano \& Ceotto, 2015).

In this context of disturbance in the light availability dynamics, some species are expected to be restricted to either closed or open environments (Rossatto et al., 2009), while others may have strategies that allow their coexistence in different areas (Rossatto \& Franco, 2017). It is observed during the seedling phase, once the development of structures is related to plant growth needs (Vieira et al., 2015). Although it varies among species and environments, the phenotypic plasticity, through variations in morphological and physiological traits, seems to be the main attribute for the adjustment of species in different light environments (Chevin et al., 2010; Matesanz et al., 2010; Valladares et al., 2000).

Quantifying the phenotypic plasticity is important to understand how species can adjust or not to environmental modifications (Gratani, 2014; Valladares et al., 2000). Pimenta pseudocaryophyllus (Gomes) Landrum (Myrtaceae), an endemic and secondary type species, popularly known as pau-cravo, was chosen due to its wide distribution, occurring in high-altitude areas in
Atlantic Forest Domain and Cerrado lato sensu (Landrum \& Kawasaki, 1997; Lorenzi, 2009; Oliveira-Filho \& Fontes, 2000; Sobral et al., 2015). Considering the replacement of forest communities by savanna due to fragmentation, deforestation, or fire for land clearing in Atlantic Forest and Cerrado areas (Franco et al., 2014; Scarano \& Ceotto, 2015), the distribution and survival of $P$. pseudocaryophyllus may be threatened.

Considering possible changes in natural light environments, it has been hypothesized that a widely distributed species such as P. pseudocaryophyllus may modify morphological structures and physiological responses, and consequently present high phenotypic plasticity in order to survive in different light availability conditions. The aim of this study was to investigate which physiological and morphological traits may confer plasticity to $P$. pseudocaryophyllus plants during their initial establishment under full sunlight and shade conditions.

\section{MATERIALS AND METHODS}

\subsection{Experimental design and plant material}

The experiment was carried out in greenhouse in the municipality of Lavras $\left(21^{\circ} 13^{\prime} 40^{\prime \prime} \mathrm{S}\right.$ and 44 57'50" W GRW), southern Minas Gerais state, Brazil. P. pseudocaryophyllus seeds were harvested in a wooded area in the municipality of Ijaci $\left(21^{\circ} 10^{\prime} 12^{\prime \prime} \mathrm{S}\right.$

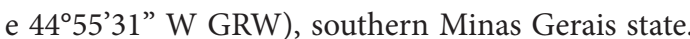
Seeds were cleaned and sown in plastic trays containing non-autoclaved washed sand substrate. They were distributed into two light environments: i) Low-density clear plastic, simulating full sunlight conditions; ii) Shade by undercover with Sombrite ${ }^{\circledast}$ shade net, with 50\% interception of short and long wave radiation. Two months after the emergence of seedlings, the most uniform individuals were selected and transplanted into Citropotes ${ }^{\circledR}(33.5 \times 14 \mathrm{~cm})$ with $4 \mathrm{~L}$ of washed sand. Plants were kept in the same environments to acclimate for 30 days. After acclimation period, they were fertilized with one-fourth strength nutritive solution, according to Malavolta (2006). Plants were evaluated for 120 days in a completely randomized design, with five replicates and two light environments. Growth analyses were performed every month. The other variables were assessed at the end of the experimental period using healthy and fully expanded leaves. 


\subsection{Monitoring of environmental conditions}

The quality and amount of light were determined at plant height in the different light environments at midday in a clear-sky day. The quality of light in each wavelength was measured using portable spectroradiometer USB-650 RED TIDE (Ocean Optics), while the photosynthetic active radiation (PAR) was measured using LI-COR Quantum Sensor Q41031 (coupled to IRGA model LI-6400XT). Daily air temperature $\left(\mathrm{T}\right.$, in $\left.{ }^{\circ} \mathrm{C}\right)$ and air relative humidity ( $\mathrm{RH}$, in \%) were measured every $3 \mathrm{~h}$ using thermohygrometer model RHT10 (Extect Instruments). Vapor pressure deficit (VPD) was calculated using temperature and relative humidity data, according to Jones (1992). Substrate field capacity was $0.21 \mathrm{~m}^{3} \cdot \mathrm{m}^{-3}$ and the amount of water needed to keep constant water availability was estimated using the ML2x TetraProbe. Irrigation was conducted every three days, aiming to keep water volumetric content $(\theta)$ between $65 \%$ and $70 \%$ field capacity. Air temperature, VPD, and water volumetric content were similar for the different treatments throughout the experimental period (Table 1).

Only PAR differed significantly between environments, decreasing $110 \%$ from full sunlight to shade, in addition to reduction in the quality in each wavelength (Table 1 , Figure 1). This way, any change of morphological or physiological traits was expected to be a result of the different light availability.

\subsection{Growth analysis}

Growth measurements were performed monthly during the experimental period. Plant height $(\mathrm{cm})$ was measured using graduated ruler, stem diameter $(\mathrm{mm})$ was measured in the same previously marked position, $1 \mathrm{~cm}$ from the soil, using digital caliper rule, and the number of leaves was counted. At the end of 120 days, specific leaf area (SLA- $\left.\mathrm{m}^{2} \cdot \mathrm{kg}^{-1}\right)$ was determined using 5 leaves per plant, using leaf area meter (CID Bio-Science, CI-203). Leaves were oven-dried and SLA was calculated dividing total leaf area by leaf dry mass. Subsequently, plants were harvested and divided into leaves, stem, and roots and dried in oven at $70{ }^{\circ} \mathrm{C}$ for $48 \mathrm{~h}$. The dried weight was used to determine the root to shoot biomass ratio (R:S ratio).

\subsection{Gas exchange and content of chloroplast pigments}

Gas exchange was evaluated between 09:00 and 11:00 a.m. using infrared gas analyzer (IRGA model LI-6400XT, LI-COR). The photosynthetic photon flux density was provided by a LED light source and set at $600 \mu \mathrm{mol} \cdot \mathrm{m}^{-2} \cdot \mathrm{s}^{-1}$ and chamber temperature was set at $25^{\circ} \mathrm{C}$. The net photosynthesis $\left(\mu \mathrm{mol} \cdot \mathrm{m}^{-2} \cdot \mathrm{s}^{-1}\right)$, stomatal conductance $\left(\mathrm{mol} \cdot \mathrm{m}^{-2} \cdot \mathrm{s}^{-1}\right)$ and transpiration values $\left(\mathrm{mmol} \cdot \mathrm{m}^{-2} \cdot \mathrm{s}^{-1}\right)$, as well as internal carbon dioxide concentration ( $\mathrm{ppm}$ ) were determined. The concentrations of chloroplast pigments, chlorophyll $a, b$, and carotenoids (xanthophylls + carotene) $\left(\mu \mathrm{g} . \mathrm{g}^{-1}\right)$ were also determined according to the method of Lichtenthaler \& Buschmann (2001).

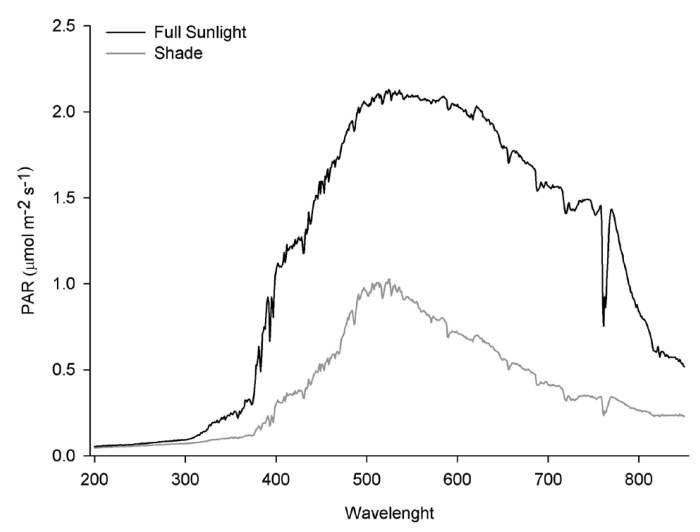

Figure 1. Incident photosynthetic active radiation at midday under two light environments: Full Sunlight (black line) and Shade (dark gray line).

Table 1. Environmental conditions of full sunlight and shade environments throughout the experimental period.

\begin{tabular}{ccc} 
Environmental Variables & \multicolumn{2}{c}{ Light Environment } \\
\cline { 2 - 3 } & Full Sunlight & Shade \\
$\operatorname{VPD}(\mathrm{kPa})$ & $2.64 \pm 0.38^{\mathrm{a}}$ & $2.25 \pm 0.37^{\mathrm{a}}$ \\
$\mathrm{PAR}\left(\mu \mathrm{mol} \cdot \mathrm{m}^{-2} \cdot \mathrm{s}^{-1}\right)$ & $592.5 \pm 64.7^{\mathrm{a}}$ & $280.7 \pm 24.1^{\mathrm{b}}$ \\
$\mathrm{T}\left({ }^{\circ} \mathrm{C}\right)$ & $27.8 \pm 1.8^{\mathrm{a}}$ & $25.1 \pm 2.6^{\mathrm{a}}$ \\
$\theta\left(\mathrm{m}^{3} \cdot \mathrm{m}^{-3}\right)$ & $0.138 \pm 0.014^{\mathrm{a}}$ & $0.147 \pm 0.022^{\mathrm{a}}$ \\
\hline
\end{tabular}

$\mathrm{VPD}=$ Vapor pressure deficit; PAR = Photosynthetic Active Radiation; $\mathrm{T}=$ daily average air temperature; $\theta=$ water volumetric content. Values followed by same letter do not show significant differences according to t-test $(\mathrm{P}<0.05)$. Values are presented as means \pm standard error. 


\subsection{Relative distance phenotypic index}

Morphological (SLA and R:S ratio) and physiological (gas exchange and content of chloroplast pigments) values were used to calculate the Relative Distance Phenotypic Index (RDPI), according to Valladares et al. (2006).

\subsection{Statistical analysis}

Growth, gas exchange and content of chloroplast pigments data were submitted to t-test $(\mathrm{P}<0.05)$. Morphological and physiological RDPI data were compared using one-way ANOVA and Tukey's test $(\mathrm{P}<0.05)$. Both analyses were performed in Sigma Plot software (version 11.0).

\section{RESULTS AND DISCUSSION}

P. pseudocaryophyllus plants grown under shade conditions showed 56\% higher net photosynthesis in comparison to full sunlight. Under that condition, higher transpiration, chlorophyll $a$ and carotenoid content were also observed (Table 2). Higher chlorophyll content was observed in plants grown under shade conditions, which is related to an increase in photosynthetic capacity under low light condition (Díaz-Barradas et al., 2018; Mathur et al., 2018; Valladares \& Niinemets, 2008). The same can be observed for carotenoid content, which function in light capture is also related to shade environments (Sánchez-Gómez et al., 2006). The results have demonstrated that P. pseudocaryophyllus have light harvesting apparatus adjusted to low light environments. Thus, when the species is adapted to low irradiance, individuals can adjust their photosynthetic apparatus by increasing the photosynthetic pigment content, transpiration, and stomatal conductance in order to use light and $\mathrm{CO}_{2}$, optimizing the photosynthetic process (Barros et al., 2012; Catoni et al., 2015; Habermann et al., 2011). In this context, the greater transpiration observed in plants under shade conditions can also contribute to higher net photosynthesis (Table 2).

There was no difference for stomatal conductance; however, in relation to intercellular $\mathrm{CO}_{2}$, plants grown under full sunlight showed result $51 \%$ higher when compared to those grown under shade conditions (Table 2). Even with the highest intercellular concentration, P. pseudocaryophyllus reduced photosynthesis when exposed to high light intensity. Additionally, the reduction in chlorophyll $a$ and carotenoid contents observed in full sunlight may indicate low acclimatization to intense radiation (Table 2).

A reduction in leaf chlorophyll content together with an increase in carotenoid contents are observed under high irradiance conditions, which are related to a reduction in light harvesting, and consequently to photodamage (Balaguer et al., 2002; Díaz-Barradas et al., 2018). In full sunlight environments, high carotenoid contents are related to energy dissipation by the xantophyll cycle, an important strategy for the reduction of photoinhibition damages (Lichtenthaler et al., 2007; Sánchez-Gómez et al., 2006). However, considering that carotenoids play a fundamental role in non-photochemical quenching mechanisms (Díaz-Barradas et al., 2018), the lower net photosynthesis observed in full sunlight may be related to a limitation of photosystem II (PSII) caused by excess radiation, since there was no stomatal limitation.

Plants from shade environments when exposed to full sunlight conditions can experience photoinhibition,

Table 2. Gas exchange characteristics and content of chloroplast pigments of Pimenta pseudocaryophyllus plants grown under full sunlight and under shade conditions.

\begin{tabular}{lcc} 
& \multicolumn{2}{c}{ Light Environments } \\
\cline { 2 - 3 } & Full Sunlight & Shade \\
Net photosynthesis $\left(\mu \mathrm{mol} \cdot \mathrm{m}^{-2} \cdot \mathrm{s}^{-1}\right)$ & $5.85 \pm 0.44^{\mathrm{b}}$ & $9.12 \pm 0.68^{\mathrm{a}}$ \\
Stomatal conductance $\left(\mathrm{mol} \cdot \mathrm{m}^{-2} \cdot \mathrm{s}^{-1}\right)$ & $0.05 \pm 0.013^{\mathrm{a}}$ & $0.06 \pm 0.004^{\mathrm{a}}$ \\
Transpiration $\left(\mathrm{mmol} \cdot \mathrm{m}^{-2} \cdot \mathrm{s}^{-1}\right)$ & $1.19 \pm 0.28^{\mathrm{b}}$ & $1.96 \pm 0.15^{\mathrm{a}}$ \\
Internal carbon concentration $(\mathrm{ppm})$ & $237.80 \pm 3.75^{\mathrm{b}}$ & $157.66 \pm 23.13^{\mathrm{a}}$ \\
Chlorophyll $a\left(\mu \mathrm{g} \cdot \mathrm{g}^{-1}\right)$ & $786.31 \pm 131.45^{\mathrm{b}}$ & $1605.15 \pm 196.02^{\mathrm{a}}$ \\
Chlorophyll $b\left(\mu \mathrm{g} \cdot \mathrm{g}^{-1}\right)$ & $585.40 \pm 126.50^{\mathrm{a}}$ & $792.70 \pm 135.18^{\mathrm{a}}$ \\
Carotenoids $\left(\mu \mathrm{g} \cdot \mathrm{g}^{-1}\right)$ & $260.66 \pm 98.03^{\mathrm{b}}$ & $382.25 \pm 30.58^{\mathrm{a}}$ \\
\hline
\end{tabular}

Values followed by same letter do not show significant differences according to t-test $(\mathrm{P}<0.05)$. Values are presented as means \pm standard error. 
which indicates PSII damage and, consequently, reduction in photosynthesis rate (Azevedo \& Marenco, 2012; Valladares et al., 2002). It appears that this species has low adjustment capacity of the photosynthetic apparatus to high irradiance, at least during the initial growth, which is worrying in the context of environmental changes.

P. pseudocaryophyllus cultivated in the environment with lower PAR showed 51\% higher increment in height and twice the number of leaves, when compared to full sunlight conditions (Figure 2). However, stem diameter remained unchanged, regardless of light environment (Figure 2). An increase of $110 \%$ in SLA of plants grown under shade conditions was also observed, while the $\mathrm{R}: \mathrm{S}$ ratio of plants cultivated in full sunlight was $20 \%$ higher (Table 3).

A reduction in SLA and preferential investment in roots indicate adjustment of P. pseudocaryophyllus under full sunlight conditions, as it allows plants to reduce their transpiration area, avoiding water loss (Catoni et al., 2015; Hoffmann et al., 2005). In addition, in open and sunny environments, plants usually show preferential biomass allocation to roots as an adjustment

Table 3. Specific leaf area (SLA) and root to shoot biomass ratio (R:S ratio) of Pimenta pseudocaryophyllus plants grown under full sunlight and under shade conditions.

\begin{tabular}{lcc} 
& \multicolumn{2}{c}{ Light Environments } \\
\cline { 2 - 3 } & Full Sunlight & Shade \\
SLA $\left(\mathrm{m}^{2} \cdot \mathrm{kg}^{-1}\right)$ & $2.72 \pm 0.08^{\mathrm{b}}$ & $4.45 \pm 0.21^{\mathrm{a}}$ \\
R:S ratio & $0.36 \pm 0.01^{\mathrm{a}}$ & $0.30 \pm 0.01^{\mathrm{b}}$ \\
\hline
\end{tabular}

Values followed by same letter do not show significant differences according to t-test $(\mathrm{P}<0.05)$. Values are presented as means \pm standard error. to reach water in deeper soil layers (Gignoux et al., 2016; Ronquim et al., 2003). However, the likely PSII photoinhibition and reduction in net photosynthesis could have caused a phenotype modification, since plants grown under full sunlight conditions showed reduction in height and number of leaves (Figure 2). High net photosynthesis rate is associated to increase in carbon gain, biomass accumulation and consequently structural growth (Oguchi et al., 2008). On the other hand, when grown in shade, $P$. pseudocaryophyllus showed preferential investment in shoots as expected for forest species (Figure 2 and Table 3). In forest environments, individuals with higher height and specific leaf area are more competitive, once they can optimize radiation absorption by increasing the possibility of light interception (Gignoux et al., 2016; Sanches et al., 2017).

The environmental conditions caused different responses in P. pseudocaryophyllus plants, allowing the quantification of phenotypic plasticity for some traits. It was observed that the R:S ratio was the least plastic trait, while transpiration was the most plastic trait (Table 4).

In the phenotypic plasticity scale (0 to 1$)$, values below 0.5 are considered low. It was observed that P. pseudocaryophyllus can be described as a species with low plasticity. According to Valladares \& Niinemets (2008), species that are shade tolerant tend to exhibit lower phenotypic plasticity, not adapting to the light pattern of open environments. Even when characteristics of higher plasticity, such for stomatal conductance, intercellular $\mathrm{CO}_{2}$, and chlorophyll $a$ and $b$ are observed, better fit of the species in the full sunlight environment was not observed, once these
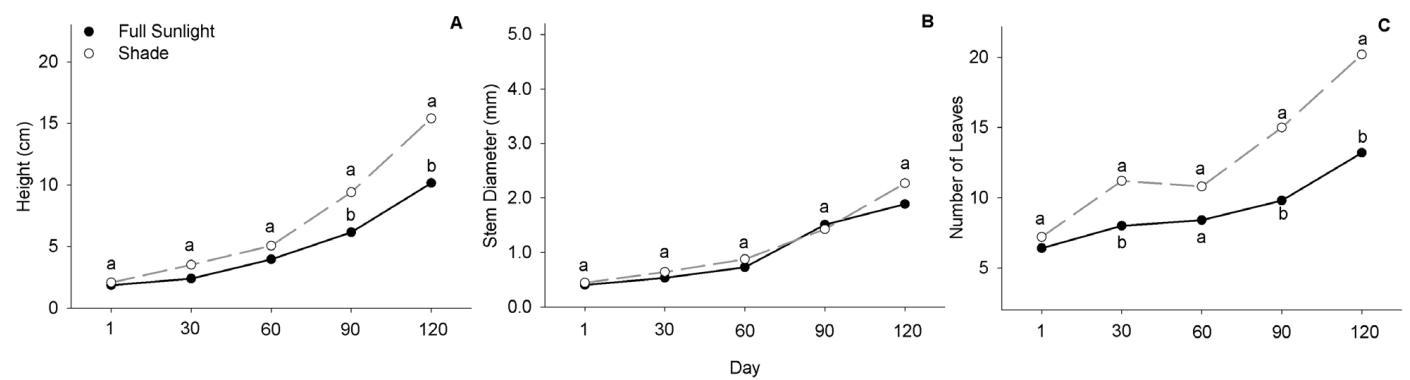

Figure 2. Shoot height (A), stem diameter (B), and number of leaves (C) of Pimenta pseudocaryophyllus plants grown under full sunlight and shade conditions. Values followed by same letter, in each evaluation day, do not show significant differences according to t-test $(\mathrm{P}<0.05)$. 
Table 4. Relative Distance Phenotypic Index (RDPI) of morphological (SLA and R:S ratio) and physiological (gas exchange and content of chloroplast pigments) traits of Pimenta pseudocaryophyllus plants grown under full sunlight and under shade conditions.

\begin{tabular}{ll}
\multicolumn{1}{c}{ Traits } & \multicolumn{1}{c}{ RDPI } \\
\hline Net photosynthesis & $0.28 \pm 0.03^{\mathrm{b}}$ \\
\hline Stomatal conductance & $0.47 \pm 0.03^{\mathrm{ab}}$ \\
\hline Transpiration & $0.52 \pm 0.03^{\mathrm{a}}$ \\
\hline Internal carbon concentration & $0.45 \pm 0.06^{\mathrm{ab}}$ \\
\hline Chlorophyll $a$ & $0.43 \pm 0.07^{\mathrm{ab}}$ \\
\hline Chlorophyll $b$ & $0.45 \pm 0.05^{\mathrm{ab}}$ \\
\hline Carotenoids & $0.14 \pm 0.03^{\mathrm{b}}$ \\
\hline SLA & $0.21 \pm 0.02^{\mathrm{b}}$ \\
\hline R:S ratio & $0.05 \pm 0.02^{\mathrm{c}}$ \\
\hline
\end{tabular}

Values followed by same letter do not show significant differences according to one-way ANOVA and Tukey's test $(\mathrm{P}<0.05)$. Values are presented as means \pm standard error.

plants showed lower photosynthesis in relation to shade species. It occurs because phenotypic plasticity may be a response to resource limitation, called passive reduction, which may represent a maladaptive response (Nicotra et al., 2010; van Kleunen \& Fischer, 2005). In this case, plasticity is not an anticipatory response to environmental threats and, consequently, it is not an adaptation strategy, but a consequence of abiotic modifications (Forsman, 2015).

Considering that phenotypic plasticity is higher for pioneer species due to the heterogeneous environments where they occur (Yuan et al., 2016), it is possible that $P$. pseudocaryophyllus, a secondary type species, may not present high plasticity. In fact, the increase in light availability is responsible for changing plant functional spaces in secondary formations (Chua \& Potts, 2018). Thus, even though P. pseudocaryophyllus has wide distribution, its low phenotypic plasticity observed in our experimental conditions may indicate low ability to occupy different environments, especially full sunlight areas. Our findings reinforce the fragility of this species and possible developmental and consequently establishment damages caused by the ongoing fragmentation events in Atlantic Forest and Cerrado areas.

\section{CONCLUSION}

Our results indicate that the adaptation of P. pseudocaryophyllus in open and sunny environments is low, which may compromise plant growth and development under these conditions. In this way, the fragmentation process in areas where P.pseudocaryophyllus occurs is extremely dangerous for the occurrence and survival of the species.

\section{ACKNOWLEDGEMENTS}

The authors thank the Fundação de Amparo à Pesquisa do Estado de Minas Gerais (FAPEMIG) under the Grant Agreement APQ 04068-10 for financial support, and the Coordenação de Aperfeiçoamento de Pessoal de Nível Superior (CAPES) for the first and fourth authors' scholarships.

\section{SUBMISSION STATUS}

Received: 28 apr., 2018

Accepted: 09 apr., 2019

\section{CORRESPONDENCE TO}

\section{Ane Mendonça}

Departamento de Biologia, Universidade Federal de Lavras - UFLA, Campus Universitário, CEP 37200-000, Lavras, MG, Brasil

E-mail: anemarcela@gmail.com

\section{FINANCIAL SUPPORT}

Fundação de Amparo à Pesquisa do Estado de Minas Gerais, (Grant/Award Number: 'APQ 04068-10').

\section{REFERENCES}

Azevedo GFC, Marenco RA. Growth and physiological changes in saplings of Minquartia guianensis and Swietenia macrophylla during acclimation to full sunlight. Photosynthetica 2012; 50(1): 86-94. http://dx.doi.org/10.1007/ s11099-012-0001-2.

Balaguer L, Pugnaire FI, Martínez-Ferri E, Armas C, Valladares F, Manrique E. Ecophysiological significance of chlorophyll loss and reduced photochemical efficiency under extreme aridity in Stipa tenacissima L. Plant and Soil 2002; 240(2): 343-352. http://dx.doi.org/10.1023/A:1015745118689.

Barros FV, Goulart MF, Telles SB, Lovato MB, Valladares F, Lemos-Filho JP. Phenotypic plasticity to light of two congeneric trees from contrasting habitats: Brazilian Atlantic Forest versus Cerrado (savanna). Plant Biology 2012; 14(1): 208-215. http://dx.doi.org/10.1111/j.14388677.2011.00474.x. PMid:21972934. 
Catoni R, Granata MU, Sartori F, Varone L, Gratani L. Corylus avellana responsiveness to light variations: morphological, anatomical, and physiological leaf trait plasticity. Photosynthetica 2015; 53(1): 35-46. http://dx.doi. org/10.1007/s11099-015-0078-5.

Chevin LM, Lande R, Mace GM. Adaptation, plasticity, and extinction in a changing environment: towards a predictive theory. PLoS Biology 2010; 8(4): 1-25. http:// dx.doi.org/10.1371/journal.pbio.1000357. PMid:20463950.

Chua SC, Potts MD. The role of plant functional traits in understanding forest recovery in wet tropical secondary forests. The Science of the Total Environment 2018; 642: 1252-1262. http://dx.doi.org/10.1016/j.scitotenv.2018.05.397. PMid:30045506.

Díaz-Barradas MC, Zunzunegui M, Alvarez-Cansino L, Esquivias MP, Valera J, Rodríguez H. How do Mediterranean shrub species cope with shade? Ecophysiological response to different light intensities. Plant Biology 2018; 20(2): 296306. http://dx.doi.org/10.1111/plb.12661. PMid:29125662.

Forsman A. Rethinking phenotypic plasticity and its consequences for individuals, populations and species. Heredity 2015; 115(4): 276-284. http://dx.doi.org/10.1038/ hdy.2014.92. PMid:25293873.

Franco AC, Rossatto DR, Silva LCR, Ferreira CS. Cerrado vegetation and global change: the role of functional types, resource availability and disturbance in regulating plant community responses to rising $\mathrm{CO} 2$ levels and climate warming. Theoretical and Experimental Plant Physiology 2014; 26(1): 19-38. http://dx.doi.org/10.1007/s40626014-0002-6.

Gignoux J, Konaté S, Lahoreau G, Le Roux X, Simioni G. Allocation strategies of savanna and forest tree seedlings in response to fire and shading: outcomes of a field experiment. Scientific Reports 2016; 6(1): 1-26. http:// dx.doi.org/10.1038/srep38838. PMid:28000732.

Gratani L. Plant phenotypic plasticity in response to environmental factors. Advances in Botany 2014; 208747: 1-17. http://dx.doi.org/10.1155/2014/208747.

Gotsch SG, Geiger EL, Franco AC, Goldstein G, Meinzer FC, Hoffmann WA. Allocation to leaf area and sapwood area affects water relations of co-occurring savanna and forest trees. Oecologia 2010; 163(2): 291-301. http:// dx.doi.org/10.1007/s00442-009-1543-2. PMid:20058025.

Habermann G, Ellsworth PFV, Cazoto JL, Simão E, Bieras AC. Comparative gas exchange performance during the wet season of three Brazilian Styrax species under habitat conditions of cerrado vegetation types differing in soil water availability and crown density. Flora 2011; 206(4): 351-359. http://dx.doi.org/10.1016/j.flora.2010.05.009.

Hoffmann WA, Franco AC, Moreira MZ, Haridasan M. Specific leaf area explains differences in leaf traits between congeneric savanna and forest trees. Functional Ecology 2005; 19(6): 932-940. http://dx.doi.org/10.1111/j.13652435.2005.01045.x.
Jones HG. Plant and microclimate: a quantitative approach to environmental plant physiology. 2nd ed. Cambridge: Cambridge University; 1992.

Landrum LR, Kawasaki ML. The genera of Myrtaceae in Brazil: an illustrated synoptic treatment and identification keys. Brittonia 1997; 49(4): 508-536. http://dx.doi. org/10.2307/2807742.

Lichtenthaler HK, Ac A, Marek MV, Kalina J, Urban O. Differences in pigment composition, photosynthetic rates and chlorophyll fluorescence images of sun and shade leaves of four tree species. Plant Physiology and Biochemistry 2007; 45(8): 577-588. http://dx.doi.org/10.1016/j. plaphy.2007.04.006. PMid:17587589.

Lichtenthaler HK, Buschmann C. Chlorophylls and carotenoids: measurement and characterization by UV-VIS spectroscopy. In: Wrolstad RE, editor. Current protocols in food analytical chemistry. New York: Wiley; 2001.

Lorenzi H. Árvores brasileiras: manual de identificação e cultivo de plantas arbóreas nativas do Brasil. 3rd ed. Nova Odessa: Instituto Plantarum; 2009.

Malavolta E. Manual de nutrição mineral de plantas. 1st ed. São Paulo: Agronômica Ceres; 2006.

Mathur S, Jain L, Jajoo A. Photosynthetic efficiency in sun and shade plants. Photosynthetica 2018; 56(1): 354-36. http://dx.doi.org/10.1007/s11099-018-0767-y.

Matesanz S, Gianoli E, Valladares F. Global change and the evolution of phenotypic plasticity in plants. Annals of the New York Academy of Sciences 2010; 1206(1): 3555. http://dx.doi.org/10.1111/j.1749-6632.2010.05704.x. PMid:20860682.

Nicotra AB, Atkin OK, Bonser SP, Davidson AM, Finnegan EJ, Mathesius $U$ et al. Plant phenotypic plasticity in a changing climate. Trends in Plant Science 2010; 15(2): 684-692. http://dx.doi.org/10.1016/j.tplants.2010.09.008. PMid:20970368.

Oguchi R, Hikosaka K, Hiura T, Hirose T. Costs and benefits of photosynthetic light acclimation by tree seedlings in response to gap formation. Oecologia 2008; 155(4): 665-675. http://dx.doi.org/10.1007/s00442-0070951-4. PMid:18193288.

Oliveira-Filho AT, Fontes MAL. Patterns of floristic differentiation among Atlantic Forests in Southeastern Brazil and the influence of climate. Biotropica 2000; 32(4b): 793-810. http://dx.doi.org/10.1111/j.1744-7429.2000. tb00619.x.

Pinheiro LFS, Kolb RM, Rossatto DR. Changes in irradiance and soil properties explain why typical non-arboreal savanna species disappear under tree encroachment. Australian Journal of Botany 2016; 64(4): 333-341. http:// dx.doi.org/10.1071/BT15283.

Ronquim CC, Prado CHBA, Paula NF. Growth and photosynthetic capacity in two woody species of Cerrado vegetation under different radiation availability. Brazilian 
Archives of Biology and Technology 2003; 46(2): 243-252. http://dx.doi.org/10.1590/S1516-89132003000200016.

Rossatto DR, Franco AC. Expanding our understanding of leaf functional syndromes in savana systems: the role of plant growth form. Oecologia 2017; 183(4): 953-962. http:// dx.doi.org/10.1007/s00442-017-3815-6. PMid:28124118.

Rossatto DR, Hoffmann WA, Franco AC. Características estomáticas de pares congenéricos de cerrado e mata de galeria crescendo numa região transicional no Brasil Central. Acta Botanica Brasílica 2009; 23(2): 499-508. http://dx.doi.org/10.1590/S0102-33062009000200021.

Rossatto DR, Takahashi FSC, Silva LCR, Franco AC. Características funcionais de folhas de sol e sombra de espécies arbóreas em uma mata de galeria no Distrito Federal, Brasil. Acta Botanica Brasílica 2010; 24(3): 640647. http://dx.doi.org/10.1590/S0102-33062010000300007.

Sanches MC, Marzinek J, Bragiola NG, Nascimento ART. Morpho-physiological responses in Cedrella fissilis Vell. submitted to changes in natural light conditions: implications for biomass accumulation. Trees 2017; 31(1): 215-227. http://dx.doi.org/10.1007/s00468-016-1474-6.

Sánchez-Gómez D, Valladares F, Zavala MA. Functional traits and plasticity in response to light in seedlings of four Iberian forest tree species. Tree Physiology 2006; 26(11): 1425-1433. http://dx.doi.org/10.1093/treephys/26.11.1425. PMid:16877327.

Scarano FR, Ceotto P. Brazilian Atlantic forest: impact, vulnerability, and adaptation to climate change. Biodiversity and Conservation 2015; 24(9): 2319-2331. http://dx.doi. org/10.1007/s10531-015-0972-y.

Silva LCR, Horwath WR. Explaining global increases in water use efficiency: why have we overestimated responses to rising atmospheric $\mathrm{CO}_{2}$ in natural forest ecosystems? PLoS One 2013; 8(1): e53089. http://dx.doi.org/10.1371/ journal.pone.0053089. PMid:23341924.

Sobral M, Proença C, Souza M, Mazine F, Lucas E. Myrtaceae in Lista de Espécies da Flora do Brasil [online]. Rio de Janeiro: Jardim Botânico do Rio de Janeiro; 2015 [cited 2018 Mar 5]. Available from: http://floradobrasil. jbrj.gov.br/jabot/floradobrasil/FB10822
Valladares F, Chico JM, Aranda I, Balaguer L, Dizengremel $\mathrm{P}$, Manrique E et al. The greater seedling high-light tolerance of Quercus robur over Fagus sylvatica is linked to a greater physiological plasticity. Trees 2002; 16(6): 395-403. http://dx.doi.org/10.1007/s00468-002-0184-4.

Valladares F, Niinemets U. Shade tolerance, a key plant feature of complex nature and consequences. Annual Review of Ecology Evolution and Systematics 2008; 39(1): 237-257. http://dx.doi.org/10.1146/annurev.ecolsys.39.110707.173506.

Valladares F, Sánchez-Gómez D, Zavala MA. Quantitative estimation of phenotypic plasticity: bridging the gap between the evolutionary concept and its ecological applications. Journal of Ecology 2006; 94(6): 1103-1116. http://dx.doi. org/10.1111/j.1365-2745.2006.01176.x.

Valladares F, Wright SJ, Lasso E, Kitajima K, Pearcy RW. Plastic phenotypic response to light of 16 congeneric shrubs from a panamanian rainforest. Ecology 2000; 81(7): 1925-1936. http://dx.doi.org/10.1890/00129658(2000)081[1925:PPRTLO]2.0.CO;2.

Vieira TO, Degli-Esposti MSO, Souza GM, Rabelo GR, Cunha M, Vitória AP. Photoacclimation capacity in seedling and sapling of Siparuna guianensis (Siparunaeae): Response to irradiance gradient in tropical forest. Photosynthetica 2015; 53(1): 11-22. http://dx.doi.org/10.1007/s11099015-0073-x.

van Kleunen M, Fischer M. Constraints on the evolution of adaptive phenotypic plasticity in plants. The New Phytologist 2005; 166(1): 49-60. http://dx.doi.org/10.1111/j.14698137.2004.01296.x. PMid:15760350.

Wu JW, Su Y, Wang JH, He Q, Qiu Q, Ma JW et al. Morphological and physiological acclimation of Catalpa bungei plantlets to different light conditions. Photosynthetica 2018; 56(2): 537-548. http://dx.doi.org/10.1007/s11099017-0706-3.

Yuan C, Wu T, Geng Y, Chai Y, Hao J. Phenotypic plasticity of lianas in response to altered light environment. Ecological Research 2016; 31(3): 375-384. http://dx.doi.org/10.1007/ s11284-016-1343-1. 